\title{
Relationship between the Differential Managemental Practices of Poultry Owners and Their Socio-Personal, Socio-Economic and Communicational Characteristics in Rajouri District of Jammu and Kashmir State
}

\author{
Mohd Saleem Choudhary ${ }^{1}$, Pranav Kumar ${ }^{1 *}$, Bharat Bhushan ${ }^{2}$ and R.A. Bafanda ${ }^{1}$ \\ ${ }^{1}$ Division of Veterinary and Animal Husbandry Extension Education, Faculty of Veterinary \\ Sciences and Animal Husbandry, SKUAST-J, R.S. Pura, Jammu-181102, India \\ ${ }^{2}$ SKUAST-J, Chatha Jammu-180009, Jammu and Kashmir, India \\ *Corresponding author
}

\section{A B S T R A C T}

Poultry production in India has taken a quantum leap in the last four decades, emerging from an entirely unorganized and unscientific farming practice to a commercial production system with state-of-the-art technological interventions. Indian commercial poultry sector has advanced remarkably due to a scientific approach adopted by the industry and an enabling environment created by the Government. The present study was conducted in in Rajouri of Jammu and Kashmir state to assess o the managemental practices of organized and unorganized sector of poultry production in Rajouri district of Jammu and Kashmir state. Rajouri district consist of 19 blocks, five blocks were selected purposely having presence of good number of poultry farmers. A compressive list of both organised and an unorganised (backyard) farm of selected blocks of Rajouri district was prepared. From the list, 12 poultry farms each from both organised and unorganised system of poultry production were selected randomly from five selected blocks, making a total of 120 respondents for the study. Multistage random sampling was adopted for the research purpose. The data was collected from 120 resplendent belonging to Nowshera Sunderban, Rajouri, Darhal and Thanamandi blocks with the help of structured interview schedule containing selected dependent and independent variables through personal interview technique. The collected data were analyzed by using suitable statistical tools such as frequency, percentage, mean, standard deviation; mean percent score (MPS) technique etc. for analysis. The studies revealed that majority of respondent in organized system were practicing semi intensive and intensive system of poultry farming, whereas, in unorganized system all respondent were practicing extensive system of poultry production in all the five districts. Majority of the respondents of organized system feed their birds 3 to 4 times and twice a day respectively where as in unorganized system the birds are released in the morning and left the birds for scavenging in the surrounding of the house. Majority of respondent feed 90 to $110 \mathrm{gm}$ feed per day in organised system while in unorganized system the birds generally fed ad-lib from scavenging. Majority per cent of respondents were providing tap water as a source of drinking water to their birds and only 8.30 per cent respondents used from natural sources such as spring waters (Chashme Wahae) while in backyard system of poultry rearing respondent use open drains as a source of drinking water. In organized system of poultry rearing that majority of respondents treat the birds by veterinary doctors while in unorganized system major 40 percent of respondents treated the birds by self-treatment followed by paravets. In organized system major cause or mortality is due to outbreak of diseases while majority respondents of unorganized system reported mortality due to the attack of predators. Coccidiosis and IBD are major disease affecting production in organised while in unorganized system respiratory problems, Fowl pox, Coccidiosis, IBD and Ranikhet diseases were reported which affects production.

\section{Introduction}

Poultry farming has been practiced in India since the prehistoric times. The Indian red jungle fowl is the acknowledge ancestor of many modern day hybrid chickens. Poultry rearing has been an integral component of livestock production system in India. Poultry 
production in India has taken a quantum leap in the last four decades, emerging from an entirely unorganized and unscientific farming practice to a commercial production system with state-of-the-art technological interventions. Indian commercial poultry sector has advanced remarkably due to a scientific approach adopted by the industry and an enabling environment created by the Government. The Indian Poultry Sector is broadly divided into organized and unorganized sub-sectors. Needs for each of the subsectors are very different. Government of India is catering to the needs of each of the subsectors through development programs of Poultry Development and for entrepreneurship development. Central Poultry Development Organizations are playing a pivotal role in the coordination and dissemination of these developmental programs of the Government. Poultry production is highly dynamic in terms of structural and management changes. In today's business environment, faster the ability to adapt to the changing system requirement, faster is the growth. However sustainability often requires dependence on other sectors like feed/ingredient inputs and processing facilities. In India, poultry sector growth may be attributed to many factors like rising incomes and a rapidly expanding middle class, together with the emergence of vertically integrated poultry producers that have reduced consumer prices by lowering production and marketing costs. Integrated production, market transition from live birds to chilled and frozen products, and policies that ensure supplies of competitively priced corn and soya bean are keys to future poultry industry growth in India. Further, disease surveillance, monitoring and control will also decide the fate of this sector.

Poultry sector in India has been growing at a much faster rate than other sectors of the Indian economy and accounts for 100 billion rupees to the Gross National Product (GNP).
Despite such amazing growth in last two decades, annual per capita consumption of egg and poultry meat in India is disappointingly low with approximately 36 eggs and 0.7 kilograms of poultry meat in 2001 (Metha et al., 2002). These levels are too low as compared to the world average of 147 eggs and 10.9 kilograms of poultry meat on a per other consumption necessities (Brahmananda 1997) capita basis (FAOSTAT). These low levels of per capita consumption of eggs and poultry meat have been mostly attributed to lower purchasing power (Gandhi and Mani, the growth rate of demand for food commodities on the 1995). Poultry farming has become a remunerative business and preeminence over all other livestock enterprises in the developing countries. It carries a scope for quick and large profit. In recent years, backyard poultry production has been extremely emphasised in sustaining and enhancing rural livelihoods. In this farming, birds are kept in low-input and low- output system and can easily be managed by women and children of the households. Now-a-days as there is growing concern about meeting of per capita requirement of protein for rural citizens of India, poultry meat and especially eggs have been proved to be the best and cheapest solution to this. Concurrently, India's unorganised and backyard poultry sector is also one of the potent tools for subsidiary income generation for many landless/ marginal farmers and also provides nutritional security to the rural poor.

\section{Materials and Methods}

The present study was carried out in Rajouri district of J\&K state. The Rajouri district was chosen purposively because it is one among the leading poultry production district of J\&K state. Rajouri district has more number of organised broiler poultry farms as well as traditional back yard poultry production system. The district was selected purposively 
to have a comparative analysis of organised and unorganized poultry production system. Rajouri district consist of 19 blocks, five blocks were selected proportionally having presence of good number of poultry farmers. A compressive list of both organised and an unorganised (backyard) farm of selected blocks of Rajouri district was prepared. From the list, 12 poultry farms each from both organised and unorganised system of poultry production were selected randomly from five selected blocks, making a total of 120 respondents for the study. Multistage random sampling was adopted for the research purpose. The data was collected from 120 resplendent belonging to Nowshera Sunderban, Rajouri, Darhal and Thanamandi blocks with the help of structured interview schedule containing selected dependent and independent variables through personal interview technique. The collected data were analyzed by using suitable statistical tools such as frequency, percentage, mean, standard deviation; mean percent score (MPS) technique etc. for analysis.

\section{Results and Discussion}

Managemental practices of different systems of poultry production

Managemental practices is a composite factor involving several components, among them knowledge regarding poultry management practices, attitude towards poultry management practices, ability in planning, ability to mobilize recourse, timely adoption, efficient use of recourse and ability in rational marketing are importance. Thus poultry managemental practices are not a unique but a complex process involving sequences and thought of action. The different aspects of poultry managemental practice in organised and unorganised system were studied through observation as well as through schedule. The different aspect such as rearing, housing management, type of housing, feeding, healthcare, etc. were presented in table 1 .

\section{Rearing system}

Table 1 reveals that majority $95 \%$ of the respondents in organized system were practicing semi intensive system of poultry farming whereas only 3\% were practicing intensive systems of poultry farming. In unorganized system all respondent were practicing backyard system of poultry production in all the five blocks as shown in table 1 . The findings are in agreement with the findings of Mishra (Mishra et al., 2000) and Ramesh (2000) reported that the broiler farmers in Vellore district of Tamil Nadu are adopting semi-intensive system of rearing hybrid broiler chicken, especially during summer. They left the birds in free range during day time with same or more floor space as it is inside the shed.

\section{Night shelter}

Under organized system all the respondents were rearing broiler and they provide separate houses. Majority of poultry owners rearing birds in unorganized system made necessary arrangements for night shelters of the bird to protect them from predators. Majority $(75 \%)$ of poultry owner in unorganized system had different shelter for night enclosure under the same roof whereas only 8.3 per cent share the same room with the family as shown in table 1. These findings are in agreements with the finding of Singh and Johari (1990) who found that the birds received housing only in the form of night shelter.

\section{Litter material provided}

The present study reveals that in organized system all the respondent provided litter material whereas none of the respondents in unorganized system of poultry production 
provided litter material but they were providing torn and used gunny bags 65 per cent and rest 35 per cent used combination of straw and dry leaves as the bedding material. In case of organized system of poultry production different types of litter material were used. Among them $83.3 \%$ use saw dust and $16.7 \%$ rice husk as the as the litter material as shown in table 1 . The findings are in agreement with the findings of Mathialagan and Subramanian (1995).

\section{Housing system in organised unorganised poultry farms}

and

Maintaining the in house temperatures is very important for sustaining the productivity from the birds. Suitable poultry housing is very important for successful poultry farming business. Poultry birds can be raised in both free range and indoor production systems. In case indoor production system, it is very crucial to manage the environment. But for sustainable commercial poultry production, planned and proper designed poultry housing is very essential to keep the poultry birds healthy and productive. And this will increase the farming production and income.

A perusal of table 2 reveals that majority of poultry owners in unorganized system $(70 \%)$ kept the birds in kacha house prepared by locally available material like mud broken bricks, tiles, and wire net where as $21.67 \%$ and $8.33 \%$ respondents kept their birds in wooden and chapper house respectively. All the respondents of organized system were providing upto 0.5 square feet space per chick and 0.8-12 square feet space in case of broiler birds. In unorganized system, the birds receive housing only in the form of night shelter and they are allowed to scavenge by themselves in the surrounding during the day time. The space provided by the poultry owners according to the flock size and some time houses were made in different tier. Table 2 reveal that the majority $(87.7 \%)$ respondents in organized system had the poultry house1 to 2 feet and rests 12.3 percent have 2 to 3 feet from the ground level whereas in unorganized system poultry houses were made at different height from the ground level. Similar findings were reported by Mathialagan and Subramanian (1995) and Singh and Johri (1990).

\section{Different arrangement made for chicks and birds practices in organised farms}

\section{Arrangement made for chicks and birds}

On perusal of table 3 it was found that all poultry farmers in the organized system had electricity connection in their poultry farms. For brooding purpose all the respondents had electric hover and bukhari (locally made heating system based on coal/wood). About 95 percent poultry farmers had made optimum temperature for their chicks and birds. All the poultry farms had chick guard. About 75 per cent poultry farmers had optimum and adequate equipments at their poultry farms.

Majority 80 per cent farms were located at less crowded place whereas 90.4 per cent farms were well connected to the road. Table 3 shows that in organized system majority $(80.2 \%)$ respondents gave $6 \mathrm{hr}$ artificial light and $19.8 \%$ respondents provide more than 6 hrs of artificial light. The findings are in agreement with the findings of Mathialagan and Subramanian (1995) who reported that lighting $(98.67 \%$ ) was provided by the most of the farmers in Namakkal district in Tamil Nadu. As per arrangement at required interval is concerned table 3 shows that all the respondents in the organized system changed litter, clean and disinfect the equipments at the certain interval. All respondents done room disinfection and white wash after some time interval respectively. The findings are in agreement with the findings of Mathialagan 
[4] who reported that the economic ability of poultry units mainly depends on scientific management. The practices like disinfection (98.67\%), water space (96\%), lighting (98.67\%), litter management (100\%), Vaccination (100\%). Coccidiost (100\%), debeaking (100\%) and deworming (80\%), were adopted by almost all respondents, whereas, the housing $(85.33 \%)$, floor space (70.67\%), sanitation $(65.33 \%)$ and culling (67\%) were not adopted by the most of the farmers in Namakkal district in Tamil Nadu.

Table.1 Different managemental practices of different systems of poultry production

\begin{tabular}{|l|c|c|}
\hline Managemental practices & Organized $(\mathbf{n = 6 0})$ & Unorganized $(\mathbf{n}=\mathbf{6 0})$ \\
\hline Rearing system & & \\
\hline Extensive & $0(0)$ & $60(100)$ \\
\hline Intensive & $3(5)$ & $0(0)$ \\
\hline Semi intensive & $57(95)$ & $0(0)$ \\
\hline Night shelters & & \\
\hline Separate house & $60(100)$ & $0(0)$ \\
\hline Shared own house & $0(0)$ & $5(8.33)$ \\
\hline Any other & $0(0)$ & $45(75)$ \\
\hline Litter materials /bedding materials & & 0 \\
\hline Saw dust & $50(83.3)$ & $0(0)$ \\
\hline Groundnut shells & $0(0)$ & 16.7 \\
\hline Paddy husk & $0(0)$ & $0(0)$ \\
\hline Rice husk & $10(16.7)$ & $(65)$ \\
\hline Gunny bags & $0(0)$ & $(35)$ \\
\hline Straw +dry leaves & 0 & \\
\hline
\end{tabular}

Table.2 Housing system in organised and unorganised poultry farms

\begin{tabular}{|l|}
\hline Housing managemental practices \\
\hline 1. Type of house \\
\hline Kacha house \\
\hline Wooden house \\
\hline Chapper house \\
\hline Space provided per bird \\
\hline Chicks \\
\hline Broiler \\
\hline Height from ground level \\
\hline 1 - 2 feet \\
\hline 2-3 feet \\
\hline
\end{tabular}

\begin{tabular}{|c|}
\hline Type of poultry farm \\
\hline Unorganised $(\mathbf{n}=\mathbf{6 0})$ \\
\hline 70 \\
\hline 21.67 \\
8.33 \\
\hline Organised $(\mathbf{n}=\mathbf{6 0})$ \\
\hline 0.5 square feet \\
$0.8-12$ square feet \\
\hline Organised $(\mathbf{n}=\mathbf{6 0})$ \\
\hline 87.7 \\
\hline 12.3 \\
\hline
\end{tabular}


Table.3 Different arrangement made for chicks and birds practices in organised farms

\begin{tabular}{|l|c|}
\hline Variable & Organised (n=60) \\
\hline Arrangement made for chicks and birds & \\
\hline Electricity supply & $60(100$ \\
\hline Chick guard & $60(100)$ \\
\hline Hover (Electric)+ Bukhari & $60(100)$ \\
\hline Optimum and adequate equipments & $45(75)$ \\
\hline Optimum temperature & $57(95)$ \\
\hline Road connection & $54.24(90.4)$ \\
\hline Less crowded place & $48(80)$ \\
\hline Artificial light provided to birds & $48.12(80.2)$ \\
\hline 6 hrs & $11.88(19.8)$ \\
\hline More than 6 hrs & \\
\hline Arrangement at required interval & $60(100)$ \\
\hline Litter changed & $60(100)$ \\
\hline Poultry house disinfected & $60(100)$ \\
\hline Cleaning and disinfection of poultry equipment & $60(100)$ \\
\hline White wash inside poultry house & \\
\hline
\end{tabular}

Table.4 Classification of the respondents according to feeding and watering material used

\begin{tabular}{|l|c|}
\hline \multicolumn{1}{|c|}{ Material } & Organised $(\mathbf{n = 6 0})$ \\
\hline Feeder & $60(100)$ \\
\hline Plastic & $0(00)$ \\
\hline Metallic & $0(00)$ \\
\hline Earthen pots & $60(100)$ \\
\hline Waterer & $0(00)$ \\
\hline Plastic & $0(00)$ \\
\hline Metallic & \\
\hline Earthen pots & \\
\hline
\end{tabular}

Table.5 Feeding system of organised and unorganised farms

\begin{tabular}{|l|c|c|}
\hline \multicolumn{1}{|c|}{ Feeding management } & Organised $(\mathbf{n = 6 0})$ & Un-Organised (n=60) \\
\hline Frequency of feeding & & $60(100)$ \\
\hline Once & $0(100)$ & $0(100)$ \\
\hline Twice & $34(56.67)$ & $0(100)$ \\
\hline 3-4 time & $26(43.33)$ & 100 \\
\hline Total & 100 & $(00)$ \\
\hline Quantity of feed (grams) & $9(15)$ & $(00)$ \\
\hline $\mathbf{7 0}$ to 90 & $36(60)$ & $(00)$ \\
\hline $\mathbf{9 0}$ to $\mathbf{1 1 0}$ & $15(25)$ & $60(100)$ \\
\hline $\mathbf{1 1 0}$ to 130 & $(00)$ & \\
\hline ad-lib & & \\
\hline
\end{tabular}


Table.6 Classification of the respondents according to time of feeding

\begin{tabular}{|c|}
\hline Time of feeding \\
\hline Morning \\
\hline Afternoon \\
\hline Evening \\
\hline Night \\
\hline Total \\
\hline
\end{tabular}

\begin{tabular}{|c|}
\hline Unorganized $(\mathrm{n}=60)$ \\
\hline $3(5)$ \\
\hline $11(18)$ \\
\hline $46(76)$ \\
\hline $0(0)$ \\
\hline $60(100)$ \\
\hline
\end{tabular}

Table.7 Classification of the respondents according to Sources of drinking water used in farms

\begin{tabular}{|c|}
\hline Sources of drinking water \\
\hline Natural source \\
\hline Tap water \\
\hline Stagnant water \\
\hline Open drain \\
\hline Frequency of watering \\
\hline Twice \\
\hline 3-4 time \\
\hline Total \\
\hline
\end{tabular}

\begin{tabular}{|c|}
\hline Organized $(\mathbf{n}=\mathbf{6 0})$ \\
\hline $5(8.3)$ \\
\hline $55(91.7)$ \\
$0(0)$ \\
$0(0)$ \\
\hline Organised $(\mathbf{n}=\mathbf{6 0})$ \\
\hline $26(43.33)$ \\
$34(56.67)$ \\
100
\end{tabular}

Table.8 Health management practices of different systems of poultry production

\begin{tabular}{|l|c|c|}
\hline \multicolumn{1}{|c|}{ Health management } & Organized (n=60) & Unorganized (n=60) \\
\hline Treatment of birds & & $1.8(3)$ \\
\hline veterinary doctors & $40.02(66.77)$ & $16.2(27)$ \\
\hline Paravets & $12.6(21)$ & $9(15)$ \\
\hline local experts/ Hakeem & $6.6(11)$ & $24(40)$ \\
\hline Self treatment & 0 & $4.2(7)$ \\
\hline No treatment & 0 & $33(55)$ \\
\hline Medicine used & $60(100)$ & $1.8(3)$ \\
\hline Allopathic medicine & $0(0)$ & $1.2(2)$ \\
\hline Ayurvedic medicine & $0(0)$ & $19.8(33)$ \\
\hline Homeopathy & $0(0)$ & $4.2(7)$ \\
\hline Home made & $0(0)$ & $0(00)$ \\
\hline No medicine & & $0(00)$ \\
\hline Type of vaccination & $60(100)$ & $0(00)$ \\
\hline Newcastle disease & $60(100)$ & \\
\hline Marek's disease & $60(100)$ & $0(00)$ \\
\hline Infectious Bursal disease & & $0(00)$ \\
\hline Source of vaccine & $48(80)$ & $0(00)$ \\
\hline Local input dealers & $9(15)$ & \\
\hline From market & $3(5)$ & \\
\hline Govt. Supply & & \\
\hline
\end{tabular}


Table.9 Mortality of birds in different systems of poultry production

\begin{tabular}{|l|c|c|}
\hline \multicolumn{1}{|c|}{ Diseases } & Organized $(\mathbf{n = 6 0 )}$ & Unorganized $(\mathbf{n = 6 0})$ \\
\hline Cause of mortality of birds & & \\
\hline Disease & $57(95)$ & $1.8(3)$ \\
\hline Chilling & $3(5)$ & $0(00)$ \\
\hline Attack of predators & $0(00)$ & $58.2(97)$ \\
\hline Disease encountered & $18(30)$ & $13.8(23)$ \\
\hline Respiratory disease & $48(80)$ & $10.2(17)$ \\
\hline IBD & $48(80)$ & $6(20)$ \\
\hline Coccidiosis & $0(00)$ & $7.2(12)$ \\
\hline Fowl pox & $7.2(12)$ & $7.2(12)$ \\
\hline Ranikhet & & \\
\hline
\end{tabular}

Feeding and watering management of organised and unorganised farms

\section{Feeding and watering material}

On perusal of table 4 it was found that all the organized poultry farmer were using plastic feederers and waterer whereas none of the farms were using either metallic or earthen pots for feeding and watering purposes.

On the other hand in unorganized system water was provided in unused utensils/bowl learthen pots kept in courtyard or birds were allot to drink water from open drains while for feeding purpose no utensil were used, grains were thrown in the courtyard for the birds to pick up. Similar findings were reported by Mathialagan and Subramanian (1995) and Singh and Johri (1995).

\section{Feeding system of organised and unorganised farms}

Nutrition management allows improvement to feed conversion ratios through optimal diet balancing and feeding regimes, and improvement to feed digestibility. An important part of raising chickens is feeding feeding makes up the major cost of production and good nutrition is reflected in the bird's performance and its products. Success on poultry production rests primarily on the quality of the bird employed, comforting environment and provision for good feed, the last being most expensive of all other inputs, deserves befitting attention.

In backyard poultry rearing, the practice prevalent in the rural area was of leaving the bird for scavenging in the morning and also giving hand full of grains. The feeding practice was very causal. The birds generally scavenged on locally available birds and seeds but in organized system of poultry rearing the birds are provided with regular feeds in their house.

Table 5 shows that a mixed type frequency of feeding pattern was observed in organized system of the study area Majority of the respondents $(56.67 \%)$ fed twice and rest $43.33 \%$ of respondents feed their birds 3 to 4 times depending on the requirements.

Where as in unorganized system the birds are released in the morning and left the birds for scavenging in the surrounding of the house, gardens, field etc. from where they fulfill their requirement of feed. From table 5 it was found that majority (60\%) of respondent feed 90 to 110 gm feed per day whereas $(25 \%)$ and 
(15\%) respondent fed 110 to $130 \mathrm{gm}$ and 70 to $90 \mathrm{gm}$ respectively. In unorganized system the birds generally fed ad-lib from scavenging. Similar findings were also reported by Dana et al., (1999), Reddy and Reddy (2000) and Scencic (2004). Singh (1988) reported that the backyard chicks that survive mainly by scavenging are an important resource for upliftment of rural landless people in India.

\section{Time of feeding}

Table 6 shows that majority (76\%) of respondents in unorganized system poultry farmers offer supplementary feeds in the evening followed by (11\%) and (3\%) respondents offer in the afternoon and morning respectively. these findings were in agreement with the findings of Dana et al., (1999), who conducted a study on animal husbandry practices among santal tribes district of West Bengal and reported that $64.98 \%$ respondents offer any feeding in addition in the evening, whereas $25.09 \%$ respondents feeds in the afternoon.

\section{Source of drinking water}

A perusal of Table 7 reveals that 91.7 per cent respondents of organized system used water from tap water and only 8.30 per cent respondents used from natural sources such as spring waters (Chashme Wahae).

All the respondents provide water to birds but its frequency varied from season to season. During summer majority of respondents $43.33 \%$ offers water to birds 3 to 4 times per day while in winter it was providing only 1 to 2 times per day.

Similar findings have been reported by Dana et al., (1999), Mathialagan and Subramanian (1995), Reddy and Reddy (2000) and Saha (2003).

\section{Health management}

\section{Health management practices of different systems of poultry production}

Management of diseases in poultry plays an important role for the progress of the industry. Birds in the commercial farms are reared in open sided houses and maintained under optimum management conditions. Birds are reared under veterinary supervision. Vaccination is regularly practiced to protect the bird against diseases. Table 8 shows that majority 66.77 per cent of respondents treat the birds by veterinary doctors. About 21 percent treated the birds by paravets local and 11 percent respondents treated the birds by local experts/Hakeem. In unorganized system major 40 percent of respondents treated the birds by self-treatment followed by paravets (27\%), local experts/ Hakeem (15\%) and veterinary doctor (3\%). About 7 per cent respondents in unorganized system did not treat their birds. These findings were also in accordance with the findings of Ramgopal et al., (2001) but in contrast with the findings of Oladduni and Fatuase (2014). Oladduni and Fatuase conducted a study on economic analysis of backyard poultry farming in Akoko North West Local Government Area of Ondo State, Nigeria and found that majority of the respondent $(84.2 \%)$ treated their sick birds by themselves while only $15.8 \%$ of them consulted veterinary doctor. This is an indication that the health care to the respondents was not significant. All the respondent of the organized system used allopathic medicine for the treatment. In unorganized system 55 per cent of respondents used allopathic medicine for the treatment of birds while 33 percent used homemade medicines, rest 3 percent ayurvedic medicine and 2 percent homeopathy table 8 . Around 7 percent don't use any medicine. All the respondent of organized system vaccinated their birds 
whereas none of the respondents in unorganized system did any vaccination of their birds. Table 8 also shows that all the respondents of organized system vaccinated their birds against Newcastle disease, Marek's disease and Infectious Bursal disease. Majority of respondents $(80 \%)$ purchase the vaccine input from the local dealers whereas $(15 \%)$ and $(5 \%)$ of the respondents got the vaccine from the market and govt. supply respectively (Table 8). The findings are in agreement with the findings of Mathialagan and Subramanian (1995), and Reddy and Reddy (2000) who reported that majority respondents of organized system vaccinated their birds. Mandal and Gautam (2003) in their study found that backyard poultry farming was an important practice among the poor and landless agriculture labourers in R.S Pura Tehsils of Jammu district and reported that vaccination of the birds was not practiced in any of the villages studied.

\section{Mortality of birds}

A perusal of table 9 shows 95 per cent of the respondents under organized system reported mortality due to outbreak of diseases and 5per cent respondents reported mortality due to chilling, huddling etc. Majority 97 percent respondents of unorganized system and 3per cent respondent of organized system reported mortality due to the attack of predators and outbreak of disease respectively. Similar findings were also reported by Prawirokusumo (1988) and Sharma et al., (2003). Prawirokusumo stated that the cause of high mortality in native chicken is probably due to lack of protection against Newcastle disease disaster and feed inadequacies during early stage of life (during the first 6 weeks of age).

Table 9 reveals that majority of respondents of the organized system (80\%) each reported that Coccidiosis and IBD. About 30\% reported Respiratory diseases in their farms. In unorganized system around 23 percent respiratory problems, 12 percent Fowl pox, 20 percent Coccidiosis, 17 percent IBD and 12 percent Ranikhet diseases were reported. The results of present study are in agreement with the results reported by Sharma Sharma et al., (2003). Who conducted a study on poultry coccidiosis in organized and backyard farms of Jammu region and found that higher prevalence of $53.61 \%$ in unorganized (backyard poultry birds) as compared to organized birds $(25.55 \%)$ was recorded. The prevalence was the highest in monsoon from both organized and unorganized manage mental practice. Also reported that poultry diseases like Coccidiosis, Salmonellosis, Ranikhet disease, chronic respiratory diseases and fowl pox were the major cause of mortality of birds. Lack of knowledge about the diseases was the main reason for this problem.

Based on finding of result it can be concluded that In J\&K organized poultry managemental practices is fairly developed and continues to develop rapidly but the study showed that there was lack of awareness about newer methods of poultry managemental practices. There is an urgent need of regular training of poultry farmers about the latest method of poultry rearing practices. Much less attention has been given to the development of unorganized poultry systems. In order to improve the nutritional and economic security of the people living in rural and inaccessible areas in a sustained manner, the promotion of back yard poultry is appropriate and actively practiced. Much more efforts are required to provide unorganized poultry farmers with latest information on the benefits of maintaining poultry in good health and productive states by supplementary feeding and vaccination. The provision of information can be done through community based, animal health care workers, NGOs and 
government organizations. Activities such as organized health management programs, with basic training covering vaccination, deworming and treatment or prevention of major diseases, should be developed further and implemented. Advice should be provided on good management procedures such as providing protective shelters/ housing for the birds to reduce predators' problems. Supplementary feeding should be encouraged to rectify malnutrition problems due to shortage of feeds.

\section{References}

Brahmananda PR. 1997. 2020 vision for Indian poultry industry. International journal of poultry science. 6:139-143

Dana SS, Khandekar N and Sharma RP. 1999. Training need of farmers about commercial poultry production. Indian Journal of Animal Health. 38(1): 45-46.

Mandal MK and Gautam. 2003. Status of backyard poultry farming in R.S. Pura Tehsil of Jammu district. Journal of Interacademica. 7(4): 491493.

Mathialagan P and Subramanian R. 1995. Extend of adoption of improved poultry practices. Journal of Extension Education. 6(2): 1130-1133.

Metha R, Nambiar RG, Singh SK, Subrahmanyanm S and Ravi C. 2002. Livestock industrialization, trend and social health environmental issues for the Indian poultry sector. Annex II, Part of IFPRI-FAO livestock industrialization project.

Mishra SP, Mohapatra BP, Dehuri PK, Mishra PK. A study on the present status of poultry farming in Orissa. Paper presented in XX Annual Conference and Symposium of Indian poultry science Association, "Challenge to Poultry industry in the new millennium", $12-14^{\text {th }}$ October, 2000, Chennai: 303-307.

Oladunni ME and Fatuase AI. 2014. Economic Analysis of Backyard Poultry Farming in Akoko North West Local Government Area of Ondo State, Nigeria. Global Journal of Biology, Agriculture and Health Sciences. 3(1): 141-147.

Pra 'wirokusumo S. 1988. Problems to improve small scale native chickens management in south-east Asian countries. Proceedings XVIII World's Poultry Congress, Nagoya, Japan.113-117.

Ram Gopal, Sachdev AK and Rajvir Singh. 2001. Study on distribution and expectation of Indian poultry industry. Indian journal of Poultry Science. 36(3):280-283

Ramesh J. 2000. Semi-Intensive system of hybrid broiler rearing. Paper presented in XX Annual Conference and Symposium of Indian poultry science Association, "Challenge to Poultry industry in the new millennium", $12-14^{\text {th }}$ October, Chennai.14-19.

Reddy GR and Reddy SJ. 2000. Extent of adoption of poultry technology by diversified farmers in Guntur District of Andhra Pradesh. Journal of Research-ANGRAU. 28(1/2): 42-50.

Saha, D. 2003. Status of rural poultry production in North 24 Paraganas district of West Bengal. M.V.Sc. Thesis, Division of Extension Education, IVRI, Izatnagar

Scencic, Antunovic Z and Speranda M. 2004. Ecological importance of litter in poultry production. Stocarstvo. 58(1): 71-78.

Sharma S, Iqbal A, Azmi S and Shah HA. 2013. Study of poultry coccidiosis in organized and backyard farms of Jammu region. Vet World. 6(8): 467469.

Singh DP and Johari DC. 1990. Kadaknath the native fowl needs to be conserved, Indian Farming. 26:19-32

Singh H. 1988. Marketing of poultry birds. Indian Journal of Animal Production and Management. 4 (3\&4): 133-138.

\section{How to cite this article:}

Mohd Saleem Choudhary, Pranav Kumar, Bharat Bhushan and Bafanda, R.A. 2018. Relationship between the Differential Managemental Practices of Poultry Owners and Their Socio-Personal, Socio-Economic and Communicational Characteristics in Rajouri District of Jammu and Kashmir State. Int.J.Curr.Microbiol.App.Sci. 7(08): 4533-4543.

doi: https://doi.org/10.20546/ijcmas.2018.708.480 